\title{
RESPON PETANI PADI SAWAH TERHADAP KEBIJAKAN INSENTIF DAN DISINSENTIF DI KOTA TASIKMALAYA, JAWA BARAT
}

\section{RESPONSE OF RICE FARMERS ON INCENTIVE AND DISCENTIVE POLICIES IN TASIKMALAYA CITY, JAWA BARAT}

\author{
Aprilliza Naura ${ }^{*}$, Lies Sulistyowati ${ }^{2}$, Maman Haeruman Karmana ${ }^{2}$ \\ ${ }^{1}$ Mahasiswa Program Studi Ilmu Ekonomi Pertanian Pascasarjana Fakultas Pertanian Universitas \\ Padjadjaran, Jl. Raya Bandung-Sumedang KM.21, Jatinangor 40363 \\ ${ }^{2}$ Dosen Program Studi Ilmu Ekonomi Pertanian Pascasarjana Fakultas Pertanian Universitas \\ Padjadjaran, Jl. Raya Bandung-Sumedang KM.21, Jatinangor 40363 \\ *E-mail: aprilliza.naura@yahoo.com \\ (Diterima 31-10-2019; Disetujui 29-11-2019)
}

\begin{abstract}
ABSTRAK
Kebijakan insentif dan disinsentif nampaknya belum ideal menjadikan petani padi mengendalikan alih fungsi lahan. Hal ini menuntut respon petani terhadap kebijakan insentif dan disinsentif yang diinginkan agar terciptanya kesesuaian antara keinginan pemerintah dan petani. Tujuan penelitian untuk mendeskripsikan karakteristik petani padi dan menganalisis respon petani terhadap kebijakan insentif dan disinsentif. Metode penelitian yaitu penelitian kuantitatif dengan jumlah responden 206 petani padi dan teknik sampel proporsionate stratified random sampling. Metode analisis karakteristik petani menggunakan analisis statistik deskriptif serta respon petani terhadap kebijakan insentif dan disinsentif menggunakan skala likert. Hasil penelitian menunjukkan karakteristik petani yaitu umur petani tergolong kelompok umur produktif; sebagian besar petani menempuh pendidikan hingga tingkat SD; petani memiliki pendapatan rendah dalam satu musim tanam yaitu Rp. 1.607.000,-; mayoritas petani termasuk dalam kategori luas lahan garapan sempit seluas $0,23 \mathrm{ha}$; Rata-rata jumlah tanggungan keluarga sebanyak 3 orang; segi pengalaman bertani memiliki ilmu dan pengalaman yang sudah cukup; dan status lahan yang mendominasi yaitu lahan sakap. Respon petani terhadap kebijakan insentif dan disinsentif rata-rata petani sangat setuju dengan kebijakan insentif dan setuju dengan kebijakan disinsentif serta sosialisasi LP2B yang tergolong cukup rendah.
\end{abstract}

Kata kunci: respon, insentif, disinsentif, konversi lahan

\begin{abstract}
It seems that the incentive and disincentive policies are not yet ideal to make rice farmers control land conversion. This requires the response of farmers to the incentive and disincentive policies that are desired in order to create a match between the wishes of the government and farmers. The purpose of the study was to describe the characteristics of rice farmers and analyze the response of farmers to incentive and disincentive policies. The research method is quantitative research with the number of respondents 206 rice farmers and the proporsionate stratified random sampling technique. The method of analyzing farmers 'characteristics uses descriptive statistical analysis and farmers' responses to incentive and disincentive policies using a Likert scale. The results showed the characteristics of farmers, namely the age of farmers classified as productive age groups; most farmers take education up to elementary school level; farmers have a low income in one growing season, which is Rp. 1,607,000; the majority of farmers are included in the narrow area of arable land area of 0.23 ha; The average number of family dependents is 3 people; in terms of farming experience having sufficient knowledge and experience; and the dominating land status is sakap land. Farmers responses to the incentive and disincentive policies on average farmers strongly agree with the incentive policy and agree with the disincentive policy and the socialization of $L P 2 B$ which is quite low.
\end{abstract}

Keywords: response, incentives, disincentives, land conversion 


\section{PENDAHULUAN}

Kota Tasikmalaya merupakan salah satu kota yang memiliki luas lahan sawah paling tinggi diantara luas lahan kota lainnya karena sektor pertanian yang merupakan tumpuan utama dalam menopang perekonomian.

Tabel 1. Total Luas Lahan Sawah Kota-Kota di Provinsi Jawa Barat

\begin{tabular}{llc}
\multicolumn{3}{c}{ Provinsi Jawa Barat } \\
\hline No & \multicolumn{1}{c}{ Kota } & $\begin{array}{c}\text { Total luas lahan sawah } \\
\text { tahun 2012-2016 } \\
\text { (ha) }\end{array}$ \\
\hline 1 & Bogor & $2.773,68$ \\
2 & Sukabumi & $7.643,45$ \\
3 & Bandung & $5.421,87$ \\
4 & Cirebon & $1.289,15$ \\
5 & Bekasi & $2.579,60$ \\
6 & Depok & 858,01 \\
7 & Cimahi & $1.032,43$ \\
8 & Tasikmalaya & $30.623,23$ \\
9 & Banjar & $16.320,68$ \\
\hline
\end{tabular}

Sumber : Badan Pusat Statistik, 2017

Menurut Peraturan Daerah Kota Tasikmalaya Nomor 4 Tahun 2012, Kota Tasikmalaya merupakan salah satu daerah yang menetapkan lahan pertanian pangan dalam Rencana Tata Ruang Wilayah (RTRW) sebagai upaya perlindungan lahan pertanian pangan abadi. Kecamatan yang termasuk dalam kawasan LP2B yaitu Kecamatan Mangkubumi, Kecamatan Kawalu, Kecamatan Purbaratu dan Kecamatan Cibeureum.

Kecamatan Purbaratu memiliki tujuh kelurahan dengan jumlah luas lahan sawah 497 ha dan mengalami penurunan luas lahan sawah sebesar 5 ha (1\%) (Dinas Pertanian Kota Tasikmlaya, 20017). Daerah penelitian dipilih Kecamatan
Purbaratu, Kota Tasikmalaya karena Kota Tasikmalaya memiliki luas lahan sawah paling tinggi di Jawa Barat, tetapi lahan pertanian semakin berkurang karena mengalami perubahan pembangunan non pertanian. Kecamatan Purbaratu termasuk dalam kawasan LP2B dan penentuan Kecamatan ini secara acak.

Kebijakan mengenai perlindungan lahan pertanian UU Republik Indonesia Nomor 41 Tahun 2009 tentang Perlindungan Lahan Pertanian Pangan Berkelanjutan (LP2B), lahan memiliki fungsi utama mendukung ketahanan pangan. Pengendalian yang diterapkan dan memiliki dasar hukum berdasarkan UU no 26 tahun 2007 tentang penataan ruang mengenai pengendalian pemanfaatan ruang dilakukan melalui kebijakan insentif dan disinsentif.

Kebijakan-kebijakan yang sudah ada ternyata masih belum ideal untuk menjadikan petani padi tetap mempertahankan lahan pertanian. Belum ada pengawasan yang konsisten dari pemerintah dan belum tersosialisasinya kebijakan dengan baik kepada petani akan kebijakan tersebut. Peninjauan kembali sangat dibutuhkan untuk kebijakan insentif dan disinsentif yang telah ada atau mendengar kebijakan baru dari petani padi di Kecamatan Purbaratu, Kota 
Tasikmalaya. Penelitian ini bertujuan untuk 1) mendeskripsikan karakteristik petani padi, dan 2) menganalisis respon petani terhadap kebijakan LP2B terutama kebijakan insentif dan disinsentif dalam pengendalian lahan pertanian.

\section{METODE PENELITIAN}

Penelitian ini didesain secara kuantitatif dengan menggunakan teknik survei. Tempat penelitian dilakukan di Kelurahan Sukaasih dan Sukamenak, Kecamatan Purbaratu, Kota Tasikmalaya pada bulan Mei 2019. Variabel penelitian terdiri dari insentif dan disinsentif pengendalian alih fungsi lahan. Besar responden sebesar 206 petani dari 424 populasi petani padi. Teknik pengambilan sampel dilakukan secara Proporsionate stratified random sampling. Teknik pengumpulan data yaitu data primer diperoleh dari responden melalui wawancara terstruktur dengan menggunakan kuesioner. Data sekunder diperoleh dari dinas pertanian, penyuluh pertanian dan Badan Pusat Stastistik. Karakteristik petani padi menggunakan analisis statistik deskriptif. Respon petani terhadap kebijakan insentif dan disinsentif dianalisis dengan skala likert.

\section{HASIL DAN PEMBAHASAN}

\section{Karakteristik Petani Padi}

Karakteristik petani padi yang diteliti yaitu umur, tingkat pendidikan formal, pendapatan usahatani, luas lahan, jumlah tanggungan keluarga, pengalaman usahatani, dan status kepemilikan lahan. Berikut penjabaran karakteristik petani:

1. Umur

Umur petani merupakan aspek penting dan salah satu faktor yang berpengaruh terhadap aktivitas di sektor pertanian. Umur petani padi sawah yang paling muda yaitu berumur 29 tahun dan 88 tahun merupakan umur yang paling tua. Rata-rata umur petani di Kelurahan Sukamenak dan Kelurahan Sukaasih yaitu 57 tahun yang diduduki oleh kelompok umur petani dengan rentang usia 53 - 64 tahun. Hal ini menunjukkan bahwa kelompok dengan rentang usia tersebut merupakan kelompok umur produktif. Berikut komposisi umur petani padi pada Tabel 2:

Tabel 2. Komposisi Umur Petani

\begin{tabular}{cccc}
\hline No & $\begin{array}{c}\text { Umur } \\
\text { (th) }\end{array}$ & $\begin{array}{c}\text { Jumlah } \\
\text { (Jiwa) }\end{array}$ & $\begin{array}{c}\text { Persentase } \\
(\%)\end{array}$ \\
\hline 1 & $29-40$ & 18 & 8,74 \\
2 & $41-52$ & 52 & 25,24 \\
3 & $53-64$ & 75 & 36,41 \\
4 & $65-76$ & 54 & 26,21 \\
5 & $77-88$ & 7 & 3,40 \\
\hline & Jumlah & 206 & 100.00 \\
\hline
\end{tabular}

Sumber: Data diolah, 2019 
Menurut Nurhasikin (2013), manusia produktif apabila memiliki usia 15-64 tahun. Usia produktif merupakan usia ideal bekerja dan mempunyai kemampuan meningkatkan produktivitas kerja serta memiliki kemampuan besar menyerap informasi dan teknologi yang inovatif di bidang pertanian.

Petani yang mendapatkan bantuan pemerintah mayoritas petani produktif dalam mengusahakan budidaya padi karena petani memiliki kerja otot yang kuat serta fungsi indera sangat baik sehingga berpengaruh terhadap keinginan petani dalam menyerap atau mengadopsi sesuatu yang baru demi mengembangkan usahatani yang lebih inovatif dan maju.

\section{Tingkat Pendidikan}

Tingkat pendidikan petani adalah jenjang atau tingkat pendidikan formal yang pernah ditempuh petani dan diukur berdasarkan lamanya petani menempuh pendidikan formal. Petani tidak ada yang menempuh pendidikan non formal. Tingkat pendidikan formal yang pernah ditempuh petani/ responden.

Tabel 3. Komposisi Pendidikan Formal Petani

\begin{tabular}{clcc}
\hline No & $\begin{array}{c}\text { Pendidikan } \\
\text { Formal }\end{array}$ & $\begin{array}{c}\text { Jumlah } \\
\text { (Jiwa) }\end{array}$ & $\begin{array}{c}\text { Persentase } \\
(\%)\end{array}$ \\
\hline 1 & Tidak Lulus SD & 0 & 0,00 \\
2 & SD & 182 & 88,35 \\
3 & SLTP & 11 & 5,34 \\
4 & SMA & 13 & 6,31 \\
5 & Perguruan Tinggi & 0 & 0,00 \\
\hline \multicolumn{2}{c}{ Jumlah } & 206 & 100,00 \\
\hline
\end{tabular}

Sumber: Data diolah, 2019
Tingkat pendidikan formal didominasi tingkat pendidikan SD sebesar $88,35 \%$. Pendidikan yang ditempuh petani tergolong rendah. Pendidikan merupakan indikator pembangunan kualitas sumber daya manusia. Pendidikan akan membawa pengaruh cukup baik dalam hal pola pikir dan sikap yang dapat ditularkan terhadap anggota kelompok lainnya, seperti yang diungkapkan Nadapdap (2014) bahwa semakin tinggi pendidikan akan semakin tinggi pula rasionalitas pola pikir dengan daya nalar yang semakin berkembang.

Petani yang berpendidikan akan meningkatkan daya tangkap, sikap, komunikasi, wawasan, akses terhadap informasi dan pasar sehingga akan lebih maju dan berkembang. Tingkat pendidikan menunjukkan pendidikan formal sebagian besar hingga tingkat SD yang berarti pola pikir maupun inovasi yang dimiliki petani tidak bisa secepat petani yang memiliki dasar pendidikan di tingkat SLTP maupun SMA untuk pengembangan usahataninya.

3. Pendapatan Usahatani Padi

$$
\text { Menurut Gustiyana (2004), }
$$
pendapatan usahatani merupakan selisih antara pendapatan kotor (output) dan biaya produksi (input) dalam satu kali musim tanam. Nilai ekonomi yang diterima petani dalam usahatani dapat 
dipergunakan untuk konsumsi dan investasi. Tingkat pendapatan yang bernilai positif merupakan konsep yang sering digunakan untuk mengukur kondisi ekonomi seseorang/ rumah tangga. Pendapatan usahatani pada penelitian ini merupakan penerimaan hasil dari kegiatan usahatani padi yang sudah dikurangi biaya total usahatani dalam satu musim tanam.

Tabel 4. Pendapatan Usahatani Padi

\begin{tabular}{clcc}
\hline No & Pendapatan/MT (Rp) & $\begin{array}{c}\text { Jumlah } \\
\text { (Jiwa) }\end{array}$ & $\begin{array}{c}\text { Persentase } \\
(\%)\end{array}$ \\
\hline 1 & $<2.502 .000$ & 164 & 79,61 \\
2 & $2.503 .000-4.961 .000$ & 30 & 14,56 \\
3 & $4.962 .000-7.419 .000$ & 10 & 4,85 \\
4 & $7.420 .000-9.877 .000$ & 1 & 0,49 \\
5 & $>9.878 .000$ & 1 & 0,49 \\
\hline & Jumlah & 206 & 100,00 \\
\hline
\end{tabular}

Sumber: Data diolah, 2019

Sebagian besar pendapatan

usahatani padi $79,61 \%$ atau kurang dari Rp. 2.502.000,- berarti petani memiliki pendapatan yang rendah dalam satu musim tanam padi sawah (4 bulan). Pendapatan rendah dikarenakan petani sedang mengalami hasil panen yang menurun dan harga gabah yang ikut menurun. Pendapatan usahatani antara $\mathrm{Rp}$. 7.420.000 sampai Rp. 9.877.000 dan yang lebih dari Rp. 9.878.000,- masing-masing sebesar $0,49 \%$ dikarenakan petani tidak hanya menggarap lahan milik namun menyakap lahan milik orang lain dalam luas lahan yang begitu luas. Rank pendapatan petani diatas merupakan pendapatan dari usahatani padi sawah.
Rata-rata pendapatan petani dalam satu kali musim tanam mendapatkan $\mathrm{Rp}$. 1.607.000,- dari luas tanam lahan garapan dengan rata-rata 0,42 hektar atau petani mendapatkan pendapatan usahatani setiap bulan sebesar Rp. 401.750,- dengan harga Rp. 4.000,-/kg. Rata-rata harga padi saat ini sebesar Rp. 4.000,- yang merupakan harga padi paling rendah. Umumnya apabila kualitas padi sedang baik, harga padi dapat mencapai Rp. 5.000,-. Harga yang relatif rendah tentu berimbas pada pendapatan petani periode tanam tersebut. 4. Luas Lahan

Lahan merupakan salah satu sumber daya yang menjadi faktor produksi utama dalam mendukung usahatani. Luas lahan yaitu ukuran luas lahan garapan yang dimiliki petani maupun lahan sakap yang dikerjakan orang lain untuk ditanami padi.

Tabel 5. Komposisi Luas Lahan Garapan Petani Padi

\begin{tabular}{|c|c|c|c|}
\hline No & Lahan Garapan (Ha) & $\begin{array}{c}\text { Jumlah } \\
\text { (Jiwa) }\end{array}$ & $\begin{array}{c}\text { Persentase } \\
(\%)\end{array}$ \\
\hline 1 & Sempit $(<0,5)$ & 146 & 70,87 \\
\hline 2 & Sedang $(0,5-2)$ & 58 & 28,16 \\
\hline 3 & Luas $(>2)$ & 2 & 0,97 \\
\hline & Jumlah & 206 & 100,00 \\
\hline
\end{tabular}

Sumber: Data diolah, 2019

Mayoritas petani $\quad 70,87 \%$

menggarap lahan usahatani padi kurang dari atau sama dengan 0,5 ha termasuk dalam kategori lahan garapan sempit. Petani mengusahakan tanaman padinya sejak lama dimana pola tanam yang digunakan hanya tanaman padi. Luas 
garapan lebih dari 2 ha sebesar $0,97 \%$ karena petani menggarap lahan milik sendiri ditambah lahan garap orang lain.

Menurut Hernanto

menggolongkan luas lahan garapan menjadi 3 kelompok yaitu: 1) lahan garapan sempit yaitu lahan yang luasnya kurang dari 0,5 hektar; 2) lahan garapan sedang yaitu lahan luasnya 0,5 sampai dengan 2 hektar; 3) lahan garapan luas yaitu lahan luasnya lebih dari 2 hektar. Sebagian besar petani menggarap lahan dengan luas yang relatif sempit dan akan terkait dengan jumlah pendapatan yang diterima petani dalam satu musim tanam.

Luas lahan usahatani akan menentukan pendapatan, taraf hidup, dan derajat kesejahteraan rumah tangga karena semakin luas lahan usahatani maka semakin tinggi hasil produksi dan semakin besar pendapatan, begitupun sebaliknya jika luas lahan yang digarap semakin kecil maka hasil produksi dan pendapatan yang didapatkan kecil. Usahatani padi untuk pemenuhan kebutuhan konsumsi rumah tangga dan sumber pendapatan serta modal usahatani selanjutnya.

5. Jumlah Tanggungan Keluarga

Jumlah tanggungan keluarga petani merupakan jumlah anggota keluarga yang menjadi tanggungan petani dalam hal pemenuhan kebutuhan hidup. Jumlah anggota keluarga yang masih menjadi tanggungan dalam keluarga berikut komposisinya:

\begin{tabular}{cccc} 
Tabel & $\begin{array}{c}\text { 6. } \\
\text { Komposisi Jumlah } \\
\text { Keluarga Petani }\end{array}$ & Tanggungan \\
\hline \multirow{2}{*}{ No } & $\begin{array}{c}\text { Jumlah Tanggungan } \\
\text { Keluarga (orang) }\end{array}$ & $\begin{array}{c}\text { Jumlah } \\
\text { (orang) }\end{array}$ & $\begin{array}{c}\text { Persentase } \\
(\%)\end{array}$ \\
\hline 1 & $8-9$ & 2 & 0,97 \\
2 & $6-7$ & 2 & 0,97 \\
3 & $4-5$ & 87 & 42,23 \\
4 & $2-3$ & 113 & 54,86 \\
5 & $0-1$ & 2 & 0,97 \\
\hline \multicolumn{4}{c}{ Jumlah } \\
\hline
\end{tabular}

Sumber: Data diolah, 2019

Jumlah tanggungan keluarga yang mendominasi $54,86 \%$ pada jumlah tanggungan 2-3 orang. Rata-rata jumlah tanggungan keluarga petani yaitu sebanyak 3 orang. Hal ini selaras dengan komposisi umur petani yang rata-rata berusia 57 tahun dimana usia tersebut petani memiliki tanggungan istri atau istri dengan satu anak yang belum menikah.

Jumlah ini cukup ideal karena jumlah tanggungan keluarga akan mengurangi total pengeluaran rumah tangga. Jumlah tanggungan lebih banyak akan mengakibatkan tingginya total pengeluaran. Petani dengan jumlah tanggungan sedikit maka total pengeluaran rendah. Menurut Martianto dan Ariani (2004), ukuran keluarga akan mempengaruhi pendapatan per kapita dan pengeluaran konsumsi rumah tangga.

Besar jumlah tanggungan keluarga menjadi motivasi petani untuk lebih giat dalam berusahatani untuk mencukupi 
tanggungan keluarga dapat terpenuhi dan memperoleh pendapatan yang cukup. Petani yang memiliki tanggungan anak akan lebih semangat karena dia sadar bahwa bukan hanya dia yang menikmati hasilnya tapi ada keluarga yaitu istri, anak, saudara bahkan orang tua yang menjadi tanggung jawabnya.

6. Pengalaman Usahatani

Pengalaman usahatani yaitu lamanya petani dalam melakukan atau menekuni kegiatan usahatani mulai dari awal hingga saat ini. Berikut tabel komposisi pengalaman usahatani:

Tabel 7. Komposisi Pengalaman Usahatani

\begin{tabular}{cccc}
\hline No & $\begin{array}{c}\text { Pengalaman } \\
\text { Usahatani (th) }\end{array}$ & $\begin{array}{c}\text { Jumlah } \\
\text { (jiwa) }\end{array}$ & $\begin{array}{c}\text { Persentase } \\
(\%)\end{array}$ \\
\hline 1 & $1-10$ & 71 & 34,47 \\
2 & $11-20$ & 79 & 38,35 \\
3 & $21-30$ & 44 & 21,36 \\
4 & $31-40$ & 7 & 3,40 \\
5 & $41-50$ & 5 & 2,42 \\
\hline & Jumlah & 206 & 100,00 \\
\hline
\end{tabular}

Sumber: Data diolah, 2019

Rata-rata pengalaman usahatani padi selama 17 tahun (11 - 20 tahun) menunjukkan petani pada dasarnya memiliki ilmu dan pengalaman yang cukup sehingga diharapkan padi yang ditanam dapat berhasil baik walaupun belum secara berkelanjutan. Pengalaman usahatani padi didominasi petani yang berpengalaman 11 hingga 20 tahun (38,35\%). Menurut Nadapdap (2014) pengalaman merupakan pengetahuan yang dimiliki dan dialami seseorang dan ditentukan sebagai hasil belajar selama hidupnya. Pengalaman usahatani merupakan pengetahuan yang diperoleh petani dari rutinitas kegiatan usahatani.

Belajar mengamati pengalaman petani lain sangat penting karena merupakan cara baik untuk mengambil keputusan dari pada dengan cara mengolah sendiri informasi yang ada. Misalnya petani mengamati dari petani lain yang mencoba sebuah inovasi baru dan menjadi proses belajar secara sadar. Pengalaman usahatani merupakan salah satu faktor yang membantu memecahkan masalah dan dianggap menjadi guru yang baik dalam usahatani. Apabila petani mempunyai pengalaman yang berhasil maka mereka mempunyai pengetahuan, sikap dan keterampilan yang lebih baik dalam usahatani.

\section{Status Kepemilikan Lahan}

Status kepemilikan lahan yaitu status lahan yang terdiri dari lahan milik, lahan sewa, lahan gadai, dan lahan sakap dari lahan yang digarap petani untuk usahatani padi.

Tabel 8. Komposisi Status Lahan yang di Garapan oleh Petani

\begin{tabular}{clcc}
\hline No & $\begin{array}{c}\text { Status Lahan } \\
\text { Garapan }\end{array}$ & $\begin{array}{c}\text { Jumlah } \\
\text { (Jiwa) }\end{array}$ & $\begin{array}{c}\text { Persentase } \\
(\%)\end{array}$ \\
\hline 1 & Lainnya & 0 & 0,00 \\
2 & Gadai & 1 & 0,49 \\
3 & Sakap & 180 & 87,37 \\
4 & Sewa & 1 & 0,49 \\
5 & Milik & 24 & 11,65 \\
\hline & Jumlah & 206 & 100,00 \\
\hline
\end{tabular}

Sumber: Data diolah, 2019 
Sebesar $87,37 \%$ lahan yang digarap, status lahan yang mendominasi yaitu lahan sakap. Luas lahan sakap (lahan yang digarap bukan oleh petani pemilik) berkisar 0,01 - 2 ha. Sebagian besar lahan yang dikerjakan penyakap merupakan lahan guntai. Menurut Harsono (2007), lahan guntai merupakan pemilikan lahan yang letaknya di luar daerah dari tempat tinggal pemilik lahan. Pemilik lahan guntai mayoritas berasal dari kota Jakarta, Ciamis, dan Bandung. Sebaiknya petani pemilik tetap turut serta dalam pengerjaan usahatani di lahan mereka, tetapi kenyataannya banyak pemilik lahan yang jarang hadir bahkan tidak pernah hadir untuk memantau lahannya. Jadi pemilik mempercayakan lahannya kepada seseorang untuk dikelola dengan baik.

Pemilik lahan guntai hanya mengetahui dan menerima hasil panen dari lahan sawah sesuai kesepakatan dengan pengelola lahan. Tanpa disadari modal usahatani padi semua dibebankan kepada penyakap. Hal ini membuat penyakap keberatan dan merasakan tidak mendapatkan hasil dari berusahatani karena harus memikirkan modal usahatani selanjutnya dan tidak diimbangi dengan hasil panen yang maksimal. Harapannya pemilik lahan guntai untuk lebih aware akan lahan milik dan tidak membebankan
$100 \%$ modal usahatani kepada penyakap supaya lahan dapat berproduksi secara maksimal serta berkelanjutan.

\section{Respon Petani Terhadap Kebijakan Insentif dan Disinsentif}

Respon dapat berupa baik atau buruk, positif atau negatif, serta menyenangkan atau tidak menyenangkan. Respon dalam penelitian ini yaitu rangsangan yang timbul dari petani terhadap LP2B serta kebijakan insentif dan disinsentif yang sudah ada dan diharapkan.

Sosialisasi menurut Ihrom (1999) adalah proses seseorang untuk memperoleh pengetahuan, keterampilan, nilai dan norma agar dapat berpartisipasi sebagai anggota dalam kelompok masyarakat. Sosialisasi Lahan Pertanian Pangan Berkelanjutan (LP2B) pernah dilakukan di Kelurahan Sukamenak dan Sukaasih. Pelaksanaannya di Kecamatan dilakukan sebanyak satu kali. Kegiatan sosialisasi dilakukan oleh Petugas Penyuluh Pertanian (PPL). Sebanyak 10 petani $(4,85 \%)$ pernah mengikuti sosialisasi LP2B. Sisanya 196 petani $(95,15 \%)$ petani tidak pernah mengikuti sosialisasi LP2B. Keterlibatan petani padi disini dalam keikutsertaan sosisalisasi LP2B masih tergolong sangat rendah. 


\begin{abstract}
Alasan mengikuti sosialisasi dikarenakan petani yang mengikuti sosialisasi adalah ketua kelompok tani. Pemberitahuan sosialisasi LP2B hanya diberitahukan kepada ketua kelompok tani. Petani lain yang bukan ketua kelompok tani, berkata bahwa tidak terdapat pemberitahuan diadakannya sosialisasi. Petani yang tidak mengikuti sosialisasi beralasan petani enggan mengikuti sosialisasi, rasa keingintahuan yang kurang, dan beranggapan sosialisasi tidak berpengaruh terhadap usahatani.
\end{abstract}

Respon petani terhadap kebijakan LP2B yaitu:
1. Respon yang berkaitan dengan pengetahuan

Aspek pengetahuan sebanyak 184 petani $(89,32 \%)$ tidak mengetahui kebijakan LP2B. Petani belum mengetahui pengertian, tujuan, manfaat, bahkan lokasi LP2B. Sisanya 22 petani $(10,68 \%)$ mengetahui LP2B yang terdiri dari pengurus kelompok tani. Jadi pengetahuan petani sangat rendah karena sosialisasi tidak dilakukan secara menyeluruh terhadap seluruh petani.

2. Respon yang berhubungan dengan sikap

a. Sikap terhadap kebijakan LP2B

Aspek sikap sebesar 100\% petani setuju adanya perlindungan lahan abadi untuk menunjang ketahanan pangan dalam kebijakan LP2B. Lahan pertanian yang diusahakan yaitu lahan sawah yang digunakan untuk mencukupi kebutuhan pangan keluarga. Apalagi dengan banyaknya investor dan pengaruh tetangga sekitar yang menjual lahannya membuat petani semakin khawatir jika lahannya ikut teralihfungsikan. Kebijakan ini diharapkan lahan sawah yang dimiliki dapat terlindungi oleh pemerintah.

b. Ketersediaan mengikuti kebijakan LP2B

Ketersediaan petani mengikuti kebijakan LP2B sebanyak 149 petani $(72,33 \%)$ setuju dan 57 petani $(27,67 \%)$ sangat setuju apabila lahannya dilindungi pemerintah melalui kebijakan LP2B. Petani mempertahankan lahan demi keberlangsungan sumber pangan petani.

3. Respon yang berhubungan dengan perilaku nyata

a. Rencana menjual lahan

Sebesar $73,79 \%$ petani sangat tidak setuju dan 26,21\% tidak setuju. Artinya petani pemilik tidak ada rencana untuk menjual lahan sawah. Petani sakap mengharapkan pemilik lahan tidak menjual lahannya karena lahan sawah merupakan ladang pangan untuk memenuhi kebutuhan keluarga dan petani merupakan pekerjaan utama. 
b. Rencana mengalihfungikan lahan

Sebesar $64,56 \%$ petani sangat tidak setuju dan $35,44 \%$ tidak setuju berarti petani tidak memiliki rencana mengalihfungsikan lahan. Petani mempertahankan lahan karena sumber utama penghasilan dan terdapat lahan sawah warisan orang tua sehingga tetap menjalankan amanah menjaga lahan sawah.

c. Mempertahankan lahan

$75,24 \%$ petani setuju dan $24,76 \%$ sangat setuju untuk tetap mempertahankan lahan dikarenakan lahan sawah merupakan sumber utama pangan. Sebagian besar responden $(98,06 \%)$ pekerjaan utamanya sebagai petani sehingga lahan menjadi sumber utama penghasilan petani. Sisanya 1,94\% responden memiliki warung dan menjadi wiraswasta serta menjadikan petani sebagai pekerjaan sampingan.

Menurut Undang-undang No. 41 Tahun 2009, pengendalian Lahan Pertanian Pangan Berkelanjutan dilakukan pemerintah melalui pemberian insentif yang merupakan upaya meningkatkan hasil produk pertanian dengan kualitas dan kuantitas yang lebih baik supaya dapat memenuhi kebutuhan pangan. Insentif merupakan bentuk melindungi dan bantuan untuk petani yang tetap mempertahankan lahan pertanian. Berikut jenis insentif yang dicanangkan pemerintah yaitu:

1. Keringanan Pajak Bumi dan Bangunan;

2. Pengembangan infrastruktur pertanian;

3. Kemudahan mengakses informasi dan teknologi;

4. Penyediaan sarana dan prasarana produksi pertanian;

5. Jaminan penerbitan sertifikat lahan pertanian pangan melalui pendaftaran tanah secara sistematik; dan

6. Penghargaan bagi petani berprestasi.

7. Insentif lainnya sesuai kewenangan Pemerintah.

Sebesar $99,51 \%$ petani menyatakan adanya insentif yang diberikan kepada petani maka akan tetap mempertahankan lahan pertanian dengan alasan petani merasa terbantu dengan insentif. Berikut beberapa jenis insentif yang diinginkan oleh petani yaitu:

1. Pembangunan Jaringan Irigasi

Pembangunan jaringan irigasi sebesar $68,45 \%$ petani setuju dan $31,55 \%$ sangat setuju. Pembangunan jaringan irigasi merupakan salah satu kebijakan insentif yang diperlukan petani dikarenakan responden yang setuju lebih kepada kondisi pengairan irigasi yang kurang baik dimana terkadang air untuk 
pengairan irigasi bercampur dengan limbah dari pembangunan perumahan. Responden yang sangat setuju di beberapa lokasi sawah masih mengandalkan musim hujan (sistem irigasi tadah hujan) untuk pengairan sawah sehingga ketika musim kemarau tiba, terjadi kekeringan bahkan petani tidak bisa menanam padi. Rata-rata keinginan responden terhadap pembangunan jaringan irigasi yaitu 4,31 berarti responden sangat setuju dengan pembangunan jaringan irigasi.

Tabel 9. Respon Petani Terhadap Insentif Pembangunan Jaringan Irigasi

\begin{tabular}{lcc}
\hline Alternatif Jawaban & $\begin{array}{c}\text { Jumlah } \\
\text { (Jiwa) }\end{array}$ & $\begin{array}{c}\text { Persentase } \\
(\%)\end{array}$ \\
\hline Sangat Tidak Setuju & 0 & 0,00 \\
Tidak Setuju & 0 & 0,00 \\
Netral & 0 & 0,00 \\
Setuju & 141 & 68,45 \\
Sangat Setuju & 65 & 31,55 \\
\hline \multicolumn{1}{c}{ Jumlah } & 206 & 100,00 \\
\hline
\end{tabular}

Sumber: Data diolah, 2019

2. Perbaikan Jalan Usahatani

Jalan usahatani di Kelurahan

Sukamenak dan Sukaasih berupa galengan (gundukan tanah yang fungsinya untuk memberi batas pada tiap petakan sawah). Sebesar 92,23\% petani setuju dan 7,77\% sangat setuju. Petani yang setuju berpendapat perbaikan jalan usahatani memudahkan petani dalam melakukan proses usahatani. Petani yang sangat setuju dikarenakan jalan usahatani di area persawahan terbilang kurang bagus dilewati dan memperlambat proses usahatani.
Jadi petani menyetujui adanya perbaikan jalan usahatani supaya dapat menunjang kinerja dalam berusahatani. Rata-rata respon terhadap perbaikan jalan usahatani sebesar 4,07 menandakan petani setuju adanya perbaikan jalan usahatani.

Tabel 10. Respon Petani Terhadap Insentif Perbaikan Jalan Usahatani

\begin{tabular}{lcc}
\hline Alternatif Jawaban & $\begin{array}{c}\text { Jumlah } \\
\text { (Jiwa) }\end{array}$ & $\begin{array}{c}\text { Persentase } \\
(\%)\end{array}$ \\
\hline Sangat Tidak Setuju & 0 & 0,00 \\
Tidak Setuju & 0 & 0,00 \\
Netral & 0 & 0,00 \\
Setuju & 190 & 92,23 \\
Sangat Setuju & 16 & 7,77 \\
\hline \multicolumn{1}{c}{ Jumlah } & 206 & 100,00 \\
\hline
\end{tabular}

Sumber: Data diolah, 2019

3. Perbaikan Kesuburan Tanah

Petani sebanyak $28,15 \%$ setuju dan $71,85 \%$ sangat setuju dengan perbaikan kesuburan lahan. Hal ini dikarenakan petani merasakan hasil panen yang menurun dan buruk secara kualitas disebabkan lahan atau tanah yang kurang subur. Jadi adanya perbaikan kesuburan tanah akan berpengaruh pada kuantitas dan kualitas padi yang dihasilkan.

Rata-rata respon petani terhadap perbaikan kesuburan tanah sebesar 4,71 berarti petani sangat setuju dengan kebijakan insentif tersebut. Petani menginginkan insentif tersebut supaya hasil panen semakin meningkat. Perbaikan kesuburan tanah dengan pemberian pupuk organik maupun kimia sesuai dengan dosis supaya tanah semakin 
subur dan berpengaruh terhadap hasil panen yang meningkat.

Tabel 11. Respon Petani Terhadap Insentif Perbaikan Kesuburan Tanah

\begin{tabular}{lcc}
\hline Alternatif Jawaban & $\begin{array}{c}\text { Jumlah } \\
\text { (Jiwa) }\end{array}$ & $\begin{array}{c}\text { Persentase } \\
(\%)\end{array}$ \\
\hline Sangat Tidak Setuju & 0 & 0,00 \\
Tidak Setuju & 0 & 0,00 \\
Netral & 0 & 0,00 \\
Setuju & 58 & 28,15 \\
Sangat Setuju & 148 & 71,85 \\
\hline \multicolumn{1}{c}{ Jumlah } & 206 & 100,00 \\
\hline
\end{tabular}

Sumber: Data diolah, 2019

4. Penyuluhan sebagai Sarana Informasi

$80,10 \%$ petani setuju dan $19,90 \%$ sangat setuju terhadap penyuluhan sebagai sarana informasi. Petani berpendapat penyuluhan merupakan wadah bagi petani untuk mengetahui informasi-informasi usahatani. Penyuluhan sangat penting dan harus tetap ditingkatkan intensitas penyuluhan karena dari penyuluhan, petani dapat berpeluang untuk meningkatkan hasil tani dan dapat mengetahui informasi atau cara dalam berusahatani yang baik dan benar. Petani dapat mengetahui cara atau solusi dalam mengatasi hambatan di lahan sawah.

Rata-rata respon petani terhadap penyuluhan sebagai sarana informasi sebesar 4,19 berarti responden setuju karena berpengaruh terhadap kelangsungan usahatani. Penyuluhan sebagai sarana dan media informasi kepada petani dalam usahatani mulai dari awal bercocok tanam hingga musim panen. Bantuan untuk usahatani dapat disalurkan melalui penyuluhan. Jadi melalui penyuluhan memiliki pengaruh terhadap usahatani.

Tabel 12. Respon Petani Terhadap Insentif Penyuluhan sebagai Sarana Informasi

\begin{tabular}{lcc}
\hline Alternatif Jawaban & $\begin{array}{c}\text { Jumlah } \\
\text { (Jiwa) }\end{array}$ & $\begin{array}{c}\text { Persentase } \\
(\%)\end{array}$ \\
\hline Sangat Tidak Setuju & 0 & 0,00 \\
Tidak Setuju & 0 & 0,00 \\
Netral & 0 & 0,00 \\
Setuju & 165 & 80,10 \\
Sangat Setuju & 41 & 19,90 \\
\hline \multicolumn{1}{c}{ Jumlah } & 206 & 100,00 \\
\hline
\end{tabular}

Sumber: Data diolah, 2019

5. Bantuan Saprodi

Bantuan sarana produksi sebesar $12,62 \%$ petani setuju dan $87,38 \%$ sangat setuju. Kebijakan insentif ini merupakan insentif yang paling diinginkan petani karena berhubungan langsung dengan kegiatan usahatani. Bantuan sarana produksi dapat meringankan atau mengurangi biaya pengeluaran usahatani. Rata-rata respon petani terhadap bantuan sarana produksi sebesar 4,87 berarti petani sangat setuju dengan bantuan saprodi.

Bantuan pemerintah kepada petani di Kelurahan Sukamenak dan Sukaasih yang diberikan diantaranya benih $25 \mathrm{~kg} /$ ha, pupuk organik $500 \mathrm{~kg} /$ ha, pupuk NPK $200 \mathrm{~kg} / \mathrm{ha}$, dan pupuk urea $300 \mathrm{~kg} / \mathrm{ha}$. Pembagian biasanya dilakukan saat diadakan penyuluhan. Pembagian bantuan saprodi kepada petani berdasarkan luas lahan garapan. Bantuan saprodi yang 
diberikan tidak selalu ada, bahkan bantuan diberikan setaun sekali.

Tabel 13. Respon Petani Terhadap Insentif Bantuan Saprodi

\begin{tabular}{lcc}
\hline Alternatif Jawaban & $\begin{array}{c}\text { Jumlah } \\
\text { (Jiwa) }\end{array}$ & $\begin{array}{c}\text { Persentase } \\
(\%)\end{array}$ \\
\hline Sangat Tidak Setuju & 0 & 0,00 \\
Tidak Setuju & 0 & 0,00 \\
Netral & 0 & 0,00 \\
Setuju & 26 & 12,62 \\
Sangat Setuju & 180 & 87,38 \\
\hline \multicolumn{1}{c}{ Jumlah } & 206 & 100,00 \\
\hline
\end{tabular}

Sumber: Data diolah, 2019

6. Bantuan Alsintan

$58,74 \%$ petani setuju dan $40,29 \%$ sangat setuju dengan bantuan alat mesin pertanian karena untuk menambah alat mesin baru dan mempercepat dalam kegiatan usahatani. Semakin banyak mesin pertanian maka saat pengolahan lahan tidak saling menunggu giliran untuk menggunakan alsintan. Beberapa petani meminjam alat pertanian kepada tetangga yang bekerja sesama petani. $0,97 \%$ petani tidak setuju karena petani sudah cukup dengan alat pertanian yang dimiliki dan mementingkan bantuan yang prioritas.

Rata-rata respon petani terhadap bantuan alsintan yaitu 4,38 berarti petani menyetujui dengan bantuan alsintan. Alat mesin pertanian yang pernah diberikan pemerintah berupa traktor. Tidak sedikit petani mengeluh karena bantuan traktor disewa sebesar Rp. 2.000,- per bata. Uang sewa digunakan untuk pemeliharaan traktor tetapi petani tidak ingin jika bantuan traktor terdapat harga sewanya.
Tabel 14. Respon Petani Terhadap Insentif Bantuan Alsintan

\begin{tabular}{lcc}
\hline \multicolumn{1}{c}{ Alternatif Jawaban } & $\begin{array}{c}\text { Jumlah } \\
\text { (Jiwa) }\end{array}$ & $\begin{array}{c}\text { Persentase } \\
(\%)\end{array}$ \\
\hline Sangat Tidak Setuju & 0 & 0,00 \\
Tidak Setuju & 2 & 0,97 \\
Netral & 0 & 0,00 \\
Setuju & 121 & 58,74 \\
Sangat Setuju & 83 & 40,29 \\
\hline \multicolumn{1}{c}{ Jumlah } & 206 & 100,00 \\
\hline Sumber:
\end{tabular}

Sumber: Data diolah, 2019

7. Pelatihan

Sebesar $84,47 \%$ petani setuju dan $14,08 \%$ sangat setuju diadakan pelatihan dengan alasan akan menambah keterampilan baru dalam usahatani. 1,45\% tidak setuju karena tidak berpengaruh dalam usahatani. Petani beranggapan lebih baik praktek langsung di lahan sawah.

Respon petani terhadap pelatihan, rata-rata 4,11 berarti petani setuju. Pelatihan yang diikuti petani yaitu mengenai cara bertanam padi dengan sistem jajar legowo. Jadwal pelaksanaan pelatihan tidak selalu rutin. Pelatihan dilaksanakan di kantor kecamatan satu kali dan di salah satu hotel. Selain itu, diberikan pelatihan mengenai usahatani padi dengan baik dan benar.

Tabel 15. Respon Petani Terhadap Insentif Pelatihan

\begin{tabular}{lcc}
\hline \multicolumn{1}{c}{ Alternatif Jawaban } & $\begin{array}{c}\text { Jumlah } \\
\text { (Jiwa) }\end{array}$ & $\begin{array}{c}\text { Persentase } \\
(\%)\end{array}$ \\
\hline Sangat Tidak Setuju & 0 & 0,00 \\
Tidak Setuju & 3 & 1,45 \\
Netral & 0 & 0,00 \\
Setuju & 174 & 84,47 \\
Sangat Setuju & 29 & 14,08 \\
\hline \multicolumn{1}{c}{ Jumlah } & 206 & 100,00 \\
\hline
\end{tabular}

Sumber: Data diolah, 2019 
8. Bantuan Keringanan PBB

Keinginan responden terhadap insentif keringanan Pajak Bumi Bangunan (PBB) didominasi petani yang setuju $81,07 \%$ dan sangat setuju sebesar $14,08 \%$. Petani yang setuju dan sangat setuju beralasan bantuan PBB meringankan beban petani sehingga dapat mengendalikan alih fungsi lahan. Petani yang tidak setuju sebesar 4,85\%, karena luas lahan yang dimiliki termasuk sempit sehingga harga PBB tidak begitu mahal.

$$
\text { Rata-rata respon petani terhadap }
$$

bantuan keringanan PBB sebesar 4,04 berarti petani setuju dengan alasan petani terbantu dengan insentif tersebut. Walaupun pembayaran dilakukan setaun sekali, tetapi sangat membantu.

Tabel 16. Respon Petani Terhadap Insentif Bantuan Keringanan PBB

\begin{tabular}{lcc}
\hline Alternatif Jawaban & $\begin{array}{c}\text { Jumlah } \\
\text { (Jiwa) }\end{array}$ & $\begin{array}{c}\text { Persentase } \\
(\%)\end{array}$ \\
\hline Sangat Tidak Setuju & 0 & 0,00 \\
Tidak Setuju & 10 & 4,85 \\
Netral & 0 & 0,00 \\
Setuju & 167 & 81,07 \\
Sangat Setuju & 29 & 14,08 \\
\hline \multicolumn{1}{c}{ Jumlah } & 206 & 100,00 \\
\hline
\end{tabular}

Sumber: Data diolah, 2019

9. Bantuan Penerbitan Sertifikat Tanah

Insentif bantuan penerbitan sertifkat tanah sebesar $83,01 \%$ setuju dan $11,17 \%$ sangat setuju karena biaya pembuatan sertifikat tanah yang mahal dan membutuhkan waktu lama dalam proses pembuatannya. Jadi petani dipermudah dengan penerbitan sertifikat tanah.
Sebesar 5,82\% petani tidak setuju karena petani penggarap lahan orang lain tidak berkaitan dengan sertifikasi tanah. Ratarata respon petani terhadap bantuan penerbitan sertifikat tanah yaitu 3,99 berarti petani setuju dengan kebijakan insentif tersebut.

Tabel 17. Respon Petani Terhadap Insentif Penerbitan Sertifikat Tanah

\begin{tabular}{lcc}
\hline \multicolumn{1}{c}{ Alternatif Jawaban } & $\begin{array}{c}\text { Jumlah } \\
\text { (Jiwa) }\end{array}$ & $\begin{array}{c}\text { Persentase } \\
(\%)\end{array}$ \\
\hline Sangat Tidak Setuju & 0 & 0,00 \\
Tidak Setuju & 12 & 5,82 \\
Netral & 0 & 0,00 \\
Setuju & 171 & 83,01 \\
Sangat Setuju & 23 & 11,17 \\
\hline \multicolumn{1}{c}{ Jumlah } & 206 & 100,00 \\
\hline Sumbr:
\end{tabular}

Sumber: Data diolah, 2019

10. Piagam Penghargaan

Piagam penghargaan merupakan bentuk apresiasi pemerintah kepada petani yang berprestasi. Sebesar $67,48 \%$ petani setuju dan 4,85\% sangat setuju. Hal ini dikarenakan piagam penghargaan sebagai wujud motivasi kepada petani supaya dapat berkarya dan bekerja lebih baik di bidang usahatani.

Sebesar 27,67\% tidak setuju karena piagam penghargaan tidak dibutuhkan dan berpengaruh terhadap usahatani. Kebanyakan petani sudah banyak yang lanjut usia. Rata-rata respon petani terhadap piagam penghargaan sebesar 3,49 berarti petani setuju piagam penghargaan sebagai bentuk apresiasi kepada petani. 
Tabel 18. Respon Petani Terhadap Insentif Piagam Penghargaan

\begin{tabular}{lcc}
\hline Alternatif Jawaban & $\begin{array}{c}\text { Jumlah } \\
\text { (Jiwa) }\end{array}$ & $\begin{array}{c}\text { Persentase } \\
(\%)\end{array}$ \\
\hline Sangat Tidak Setuju & 0 & 0,00 \\
Tidak Setuju & 57 & 27,67 \\
Netral & 0 & 0,00 \\
Setuju & 139 & 67,48 \\
Sangat Setuju & 10 & 4,85 \\
\hline \multicolumn{1}{c}{ Jumlah } & 206 & 100,00 \\
\hline
\end{tabular}

Sumber: Data diolah, 2019

\section{Modal Uang}

Insentif modal uang sebesar $72,82 \%$ petani setuju dan $27,18 \%$ sangat setuju. Hal ini dikarenakan bantuan berupa uang, petani dapat dengan fleksibel mengurus usahatani dan mengatur biaya pengeluaran modal usahatani. Bantuan modal uang merupakan insentif baru dari keinginan para petani. Rata-rata respon petani terhadap bantuan modal uang sebesar 4,27 berarti petani sangat setuju dengan bantuan modal uang karena petani dapat mengatur biaya pengeluaran.

Tabel 19. Respon Petani Terhadap Insentif Modal Uang

\begin{tabular}{lcc}
\hline Alternatif Jawaban & $\begin{array}{c}\text { Jumlah } \\
\text { (Jiwa) }\end{array}$ & $\begin{array}{c}\text { Persentase } \\
(\%)\end{array}$ \\
\hline Sangat Tidak Setuju & 0 & 0,00 \\
Tidak Setuju & 0 & 0,00 \\
Netral & 0 & 0,00 \\
Setuju & 150 & 72,82 \\
Sangat Setuju & 56 & 27,18 \\
\hline \multicolumn{1}{c}{ Jumlah } & 206 & 100,00 \\
\hline
\end{tabular}

Sumber: Data diolah, 2019

12. Pemberian Kompensasi

Pemberian kompensasi didapatkan sebesar $84,95 \%$ petani setuju dan $15,05 \%$ sangat setuju. Hal ini dikarenakan dapat meringankan beban petani dalam usahatani. Rata-rata respon petani terhadap pemberian kompensasi sebesar 4,15 berarti petani setuju dengan pemberian kompensasi.

Bagi petani sangat berpengaruh karena adanya kompensasi petani mendapatkan uang atau fasilitas pendukung untuk usahatani mereka dan selain itu kompensasi disini dapat berupa pemberian upah untuk buruh tani.

Tabel 20. Respon Petani Terhadap Insentif Pemberian Kompensasi

\begin{tabular}{lcc}
\hline Alternatif Jawaban & $\begin{array}{c}\text { Jumlah } \\
\text { (Jiwa) }\end{array}$ & $\begin{array}{c}\text { Persentase } \\
(\%)\end{array}$ \\
\hline Sangat Tidak Setuju & 0 & 0,00 \\
Tidak Setuju & 0 & 0,00 \\
Netral & 0 & 0,00 \\
Setuju & 175 & 84,95 \\
Sangat Setuju & 31 & 15,05 \\
\hline \multicolumn{1}{c}{ Jumlah } & 206 & 100,00 \\
\hline
\end{tabular}

Sumber: Data diolah, 2019

\section{Insentif Prioritas}

Insentif prioritas yaitu jenis insentif yang paling diprioritaskan petani. Insentif yang menjadi prioritas utama dibagi berdasarkan status kepemilikan lahan.

Tabel 21 menunjukkan petani gadai lebih memprioritaskan insentif bantuan sarana dan produksi. Petani yang memiliki lahan gadai bernama Ibu Ade Kiki. Beliau memilih bantuan sarana dan produksi dikarenakan sangat membutuhkan bantuan saprodi seperti benih dan pupuk. Harga benih dan pupuk di toko pertanian yang cukup mahal membuat petani terkadang terbebani sehingga sangat terbantu dengan bantuan sarana produksi 
berupa benih dan pupuk. Prioritas kedua memilih bantuan alsintan dikarenakan alat pertanian milik $\mathrm{Bu}$ Ade sudah ada yang rusak dan belum memiliki persediaan atau tambahan alat supaya lebih cepat untuk bekerja di lahan. Prioritas ketiga yaitu modal uang. Hal ini dikarenakan bantuan saprodi yang tidak datang setiap saat petani membutuhkan, jadi bantuan modal uang yang lebih praktis dan dapat mengatur pengeluaran modal usahatani.

Tabel 21. Insentif Prioritas

\begin{tabular}{|c|c|c|c|}
\hline $\begin{array}{c}\text { Status } \\
\text { Kepemilikan }\end{array}$ & $\begin{array}{l}\text { Jumlah } \\
\text { (orang) }\end{array}$ & Prioritas & Jenis Insentif \\
\hline \multirow{3}{*}{ Gadai } & \multirow{3}{*}{$(1-8)$} & 1 & $\begin{array}{l}\text { Bantuan } \\
\text { sarana dan } \\
\text { produksi }\end{array}$ \\
\hline & & 2 & $\begin{array}{l}\text { Bantuan } \\
\text { alsintan }\end{array}$ \\
\hline & & 3 & Modal uang \\
\hline \multirow{3}{*}{ Sakap } & \multirow{3}{*}{180} & 1 & $\begin{array}{l}\text { Perbaikan } \\
\text { kesuburan } \\
\text { lahan }\end{array}$ \\
\hline & & 2 & $\begin{array}{l}\text { Bantuan } \\
\text { sarana dan } \\
\text { produksi }\end{array}$ \\
\hline & & 3 & Modal uang \\
\hline \multirow{3}{*}{ Sewa } & \multirow{3}{*}{1} & 1 & $\begin{array}{l}\text { Perbaikan } \\
\text { kesuburan } \\
\text { lahan }\end{array}$ \\
\hline & & 2 & $\begin{array}{l}\text { Bantuan } \\
\text { sarana dan } \\
\text { produksi }\end{array}$ \\
\hline & & 3 & $\begin{array}{l}\text { Bantuan } \\
\text { alsintan }\end{array}$ \\
\hline \multirow{3}{*}{ Milik } & \multirow{3}{*}{24} & 1 & $\begin{array}{l}\text { Perbaikan } \\
\text { kesuburan } \\
\text { lahan }\end{array}$ \\
\hline & & 2 & $\begin{array}{l}\text { Bantuan } \\
\text { sarana dan } \\
\text { produksi }\end{array}$ \\
\hline & & 3 & $\begin{array}{l}\text { Bantuan } \\
\text { alsintan }\end{array}$ \\
\hline
\end{tabular}

Sumber: Data diolah, 2019
Status lahan sakap $(87,37 \%)$ memilih insentif prioritas utama yaitu perbaikan kesuburan lahan dengan pemberian pupuk karena mengingat harga pupuk yang mahal serta modal yang dimiliki petani terbatas. Kebutuhan pupuk sangat diperlukan untuk kesuburan lahan sawah agar lahan sawah dapat subur dan menghasilkan produksi yang meningkat. Prioritas kedua yaitu bantuan sarana dan produksi karena tidak dipungkiri petani membutuhkan bantuan berupa benih, pestisida dan pupuk yang dapat meringankan beban dalam meminimalisir biaya usahatani karena seluruh modal ditanggung petani sakap. Prioritas ketiga yaitu modal uang karena akan membantu petani dalam modal usahatani dan kebutuhan harian keluarga.

Status kepemilikan lahan sewa sebanyak 1 petani bernama Bapak Ucu memilih insentif prioritas pertama yaitu perbaikan kesuburan lahan. Lahan yang subur dapat diperbaiki dengan penggunaan pupuk sesuai dengan dosisnya. Jadi kebutuhan pupuk sangat diperlukan untuk kesuburan lahan. Prioritas kedua yang dibutuhkan yaitu bantuan saprodi. Bantuan berupa benih, pestisida, dan pupuk dibutuhkan petani dalam meringankan biaya pengeluaran di lahan. Insentif prioritas ketiga yaitu 
bantuan alsintan karena alat pertanian yang dimiliki berjumlah satu buah. Jadi lebih cepat pengerjaan di lahan jika memiliki alat pertanian lebih dari satu.

Status kepemilikan lahan milik yaitu 24 orang $(11,65 \%)$ memilih jenis insentif prioritas yang pertama perbaikan kesuburan lahan, kedua bantuan saprodi pertanian, dan ketiga bantuan alsintan. Petani pemilik membutuhkan prioritas pupuk untuk kesuburan lahan sehingga produksi meningkat secara kualitas dan kuantitas. Bantuan sarana produksi berupa benih, pupuk, dan pestisida dibutuhkan untuk meringankan beban petani.

Jadi dapat ditarik kesimpulan dari keempat status kepemilikan lahan, petani lebih memprioritaskan bantuan pupuk untuk memperbaiki kesuburan lahan. Harga pupuk yang kurang terjangkau bagi petani menjadi hambatan dalam berusahatani. Terkadang modal yang dikeluarkan tidak sebanding dengan hasil panen yang diterima sehingga mengalami kerugian. Bantuan pupuk pasti sangat membantu dan meringankan petani terutama dalam hal memperbaiki kesuburan lahan. Menurut Hairiah (2000) pemberian pupuk organik serta pupuk lain dapat meningkatkan perbaikan kesuburan tanah. Pengaruh pupuk organik dalam memperbaiki kesuburan tanah kurang spontan tetapi pengaruhnya lebih tahan lama. Pupuk kimia pengaruhnya spontan tetapi hanya tahan beberapa minggu atau bulan.

\section{Kebijakan Disinsentif}

Peraturan Daerah Kota Tasikmalaya Nomor 4 Tahun 2012 tentang Rencana Tata Ruang Wilayah Kota Tasikmalaya Tahun 2011-2031 kebijakan disinsentif adalah perangkat untuk mencegah, membatasi, atau mengurangi pelaksanaan kegiatan yang tidak sejalan dengan rencana tata ruang dan apabila melakukan pelanggaran akan mendapatkan hukuman.

Bentuk kebijakan disinsentif menurut Isa (2004) diantaranya bentuk peninjauan kembali hak atas lahan dan pengenaan pajak yang tinggi. Disinsentif dibuat untuk menunjang keberhasilan program LP2B. Tujuan disinsentif supaya alih fungsi lahan dapat terkendali dan agar dapat berjalan sesuai peraturan. Berikut jenis disinsentif yaitu diantaranya:

\section{Pengenaan Pajak Tinggi}

Sebesar $60,19 \%$ petani setuju dan $6,31 \%$ sangat setuju yang dikarenakan adanya pengenaan pajak tinggi akan mengendalikan alih fungsi lahan. Sebanyak $4,37 \%$ petani berpendapat sangat tidak setuju dan $29,13 \%$ tidak setuju yang dikarenakan petani merasa 
diberatkan dengan disinsentif tersebut.

Pasti akan berpengaruh terhadap petani sakap karena jika petani pemilik menjual lahan maka petani sakap yang mengerjakan lahan tersebut akan kehilangan pekerjaannya. Respon petani terhadap pengenaan pajak tinggi sebesar 3,34 artinya petani netral dimana pemberian pajak yang tinggi pasti akan memberatkan petani khususnya petani pemilik.

Tabel 22. Respon Petani Terhadap Disinsentif

\begin{tabular}{lcc}
\multicolumn{3}{c}{ Pengenaan Pajak Tinggi } \\
\hline \multirow{2}{*}{ Alternatif Jawaban } & $\begin{array}{c}\text { Jumlah } \\
\text { (Jiwa) }\end{array}$ & $\begin{array}{c}\text { Persentase } \\
(\%)\end{array}$ \\
\hline Sangat Tidak Setuju & 9 & 4,37 \\
Tidak Setuju & 60 & 29,13 \\
Netral & 0 & 0,00 \\
Setuju & 124 & 60,19 \\
Sangat Setuju & 13 & 6,31 \\
\hline \multicolumn{1}{c}{ Jumlah } & 206 & 100,00 \\
\hline
\end{tabular}

Sumber: Data diolah, 2019

2. Pembatasan Penyediaan Infrastruktur

Pembatasan penyediaan

infrastruktur sebesar $69,90 \%$ petani setuju dan $1,94 \%$ sangat setuju dikarenakan infrastruktur sangat penting dan berpengaruh bagi usahatani. Jadi jika disinsentif ini diberlakukan, maka petani tetap mempertahankan lahan sehingga lahan sawah tetap ada dan pekerjaan utama sebagai petani tidak hilang. 0,49\% petani sangat tidak setuju dan 27,67\% tidak setuju. Petani merasa dengan infrastruktur yang dibatasi akan menghambat proses usahatani dan membuat petani semakin dibebani.
Respon petani terhadap pembatasan penyediaan infrastruktur sebesar 3,45 berarti rata-rata petani setuju dikarenakan petani mendukung jenis disinsentif ini supaya lahan sawah tidak ada yang dialihfungsikan menjadi non pertanian.

Tabel 23. Respon Petani Terhadap Disinsentif Pembatasan Penyediaan Infrastruktur

\begin{tabular}{lcc}
\hline Alternatif Jawaban & $\begin{array}{c}\text { Jumlah } \\
\text { (Jiwa) }\end{array}$ & $\begin{array}{c}\text { Persentase } \\
(\%)\end{array}$ \\
\hline Sangat Tidak Setuju & 1 & 0,49 \\
Tidak Setuju & 57 & 27,67 \\
Netral & 0 & 0,00 \\
Setuju & 144 & 69,90 \\
Sangat Setuju & 4 & 1,94 \\
\hline \multicolumn{1}{c}{ Jumlah } & 206 & 100,00 \\
\hline
\end{tabular}

Sumber: Data diolah, 2019

3. Pengenaan Sanksi/ Denda

Respon terhadap dikenakannya sanksi/ denda sebesar $81,07 \%$ petani setuju dan sebesar $4,85 \%$ sangat setuju dengan jenis disinsentif ini. Petani setuju dan sangat setuju karena apabila petani melakukan alih fungsi lahan akan merasa jera dengan diberikannya sanksi/ denda. Jadi dapat mengendalikan alih fungsi lahan. Sebesar $14,08 \%$ petani tidak setuju dikarenakan dengan diberikan sanksi/ denda petani merasa keberatan. Petani terbebani diberikannya sanksi atau membayar denda berupa uang karena uang denda lebih baik digunakan untuk modal usahataninya.

Respon petani terhadap pengenaan sanksi/ denda sebesar 3,76 artinya petani masih setuju dengan adanya disinsentif 
ini. Petani berpendapat selain untuk pengendalian alih fungsi lahan, tetapi petani masih adanya kesadaran untuk menjaga lahan sawah tetap ada.

Tabel 24. Respon Petani Terhadap Disinsentif Pengenaan Sanksi/ Denda

\begin{tabular}{lcc}
\hline Alternatif Jawaban & $\begin{array}{c}\text { Jumlah } \\
\text { (Jiwa) }\end{array}$ & $\begin{array}{c}\text { Persentase } \\
(\%)\end{array}$ \\
\hline Sangat Tidak Setuju & 0 & 0,00 \\
Tidak Setuju & 29 & 14,08 \\
Netral & 0 & 0,00 \\
Setuju & 167 & 81,07 \\
Sangat Setuju & 10 & 4,85 \\
\hline \multicolumn{1}{c}{ Jumlah } & 206 & 100,00 \\
\hline
\end{tabular}

Sumber: Data diolah, 2019

\section{Pengetatan Izin IMB/ Sertifikat}

Sebesar $70,87 \%$ petani setuju dan $27,67 \%$ sangat setuju. Hal ini karena diperketatnya perijinan IMB (Izin Mendirikan Bangunan) maka membuat petani mengurungkan niatnya dalam mengalihfungsikan lahan pertanian sehingga lahan sawah tetap abadi. Terdapat $1,46 \%$ petani tidak setuju dikarenakan petani menjadi kesusahan dalam proses perijinan membangun lahan menjadi non pertanian dimana lahan yang dimiliki menjadi hak petani sepenuhnya.

Respon petani terhadap pengetatan ijin IMB sebesar 4,24 artinya petani sangat setuju karena lahan sawah merupakan ladang pekerjaan utama petani. Apabila lahan sawah diubah menjadi non pertanian, maka petani akan kehilangan pekerjaannya. Selain itu petani sadar akan dampak buruk untuk lahan sawah diganti menjadi lahan non pertanian.

Tabel 25. Respon Petani Terhadap Disinsentif Pengetatan Izin IMB/ Sertifikat

\begin{tabular}{lcc}
\hline Alternatif Jawaban & $\begin{array}{c}\text { Jumlah } \\
\text { (Jiwa) }\end{array}$ & $\begin{array}{c}\text { Persentase } \\
(\%)\end{array}$ \\
\hline Sangat Tidak Setuju & 0 & 0,00 \\
Tidak Setuju & 3 & 1,46 \\
Netral & 0 & 0,00 \\
Setuju & 146 & 70,87 \\
Sangat Setuju & 57 & 27,67 \\
\hline \multicolumn{1}{c}{ Jumlah } & 206 & 100,00 \\
\hline
\end{tabular}

Sumber: Data diolah, 2019

5. Pinalti

Respon petani terhadap pinalti yaitu $70,87 \%$ petani setuju dan $5,83 \%$ sangat setuju. Hal ini dikarenakan selain petani akan mengurungkan niat untuk mengalihfungsikan lahan, petani sadar akan pentingnya lingkungan hijau. Terdapat petani sangat tidak setuju sebesar $0,97 \%$ dan $22,33 \%$ petani tidak setuju. Ketidaksetujuan dikarenakan akan memberatkan petani padahal lahan sepenuhnya merupakan milik petani.

Tabel 26. Respon Petani Terhadap Disinsentif Pinalti

\begin{tabular}{|l|c|c|}
\hline Alternatif Jawaban & $\begin{array}{c}\text { Jumlah } \\
\text { (Jiwa) }\end{array}$ & $\begin{array}{c}\text { Persentase } \\
(\mathbf{\%})\end{array}$ \\
\hline Sangat Tidak Setuju & 2 & 0,97 \\
\hline Tidak Setuju & 46 & 22,33 \\
\hline Netral & 0 & 0,00 \\
\hline Setuju & 146 & 70,87 \\
\hline Sangat Setuju & 12 & 5,83 \\
\hline \multicolumn{1}{|c|}{ Jumlah } & 206 & 100,00 \\
\hline
\end{tabular}

Sumber: Data diolah, 2019

Rata-rata sebesar 3,58 berarti petani setuju dengan jenis disinsentif ini. Petani tidak ingin lahan sawah berubah menjadi lahan non pertanian karena selain pekerjaan utama mereka akan hilang 
sebagai petani, akan mendapatkan dampak adanya perubahan tersebut.

6. Pencabutan Insentif yang Telah

Diberikan

Pencabutan insentif yang telah diberikan didapatkan sebesar $73,30 \%$ petani setuju dan $21,36 \%$ sangat setuju dikarenakan petani akan kesusahan jika insentif yang telah diberikan dicabut maka petani mengurungkan niat untuk alih fungsi lahan sehingga lahan sawah akan tetap ada. Sebesar 5,34\% petani tidak setuju dikarenakan keberatan apabila insentif yang telah diberikan oleh pemerintah dicabut begitu saja dan biaya pengeluaran petani juga akan semakin besar jika tanpa adanya bantuan insentif. Rata-rata respon petani terhadap pencabutan insentif yang telah diberikan yaitu 4,10 artinya petani setuju dengan pencabutan insentif yang telah diberikan. Petani menginginkan lahan hijau atau lahan sawah tidak hilang.

Tabel 27. Respon Petani Terhadap Disinsentif Pencabutan Insentif yang Telah Diberikan

\begin{tabular}{lcc}
\hline Alternatif Jawaban & $\begin{array}{c}\text { Jumlah } \\
\text { (Jiwa) }\end{array}$ & $\begin{array}{c}\text { Persentase } \\
(\%)\end{array}$ \\
\hline Sangat Tidak Setuju & 0 & 0,00 \\
Tidak Setuju & 11 & 5,34 \\
Netral & 0 & 0,00 \\
Setuju & 151 & 73,30 \\
Sangat Setuju & 44 & 21,36 \\
\hline \multicolumn{1}{c}{ Jumlah } & 206 & 100,00 \\
\hline
\end{tabular}

Sumber: Data diolah, 2019

Rata-rata petani setuju dengan disinsentif karena sebagian besar petani sakap (petani yang menggarap lahan milik orang lain dimana pemiliknya tidak tinggal di daerah tersebut). Mayoritas petani sebagai pekerjaan utama untuk memenuhi kebutuhan hidup. Pemilik lahan menyetujui disinsentif yang pada dasarnya tidak ada niat menjual dikarenakan lahan sawah warisan orang tuanya terdahulu.

Rata-rata respon petani sebesar 4,21 artinya petani sangat setuju apabila kebijakan insentif diterapkan. Petani akan sangat terbantu dengan diberikan bantuan insentif. Seluruh modal dibebankan seluruhnya kepada petani sakap yang sangat membebankan karena modal yang dikeluarkan tidak sebanding dengan panen yang dihasilkan. Menurut Wijayanti (2016) salah satu tujuan pemberian insentif untuk meningkatkan upaya pengendalian alih fungsi Lahan Pertanian Pangan Berkelanjutan, pemberdayaan, pendapatan, dan kesejahteraan petani. Pendapat lain Rantini dan Prabatmodjo (2013) petani memandang positif kebijakan perlindungan lahan pertanian pangan berkelanjutan. Mereka memerlukan insentif yang ditawarkan guna pengembangan usahatani.

Kebijakan disinsentif didapatkan sebesar 3,75 yang berarti bahwa seluruh petani setuju apabila kebijakan disinsentif 
(hukuman akibat pelanggaran) diterapkan, karena petani sebagai pekerjaan utama dan lahan sawah menjadi sumber penghasilan utama. Jadi dengan diberlakukannya kebijakan disinsentif akan memberikan efek jera dan mengurungkan niat untuk melakukan alih fungsi lahan. Petani ingin lahan pertanian tetap abadi untuk keberlangsungan hidup. Menurut Wibowo (1996) tingginya motif petani mempertahankan lahan sawah dikarenakan persepsi kerugian akibat alih fungsi lahan sawah yang berdampak negatif dianggap sebagai suatu persoalan dalam jangka panjang. Selain itu menurut Rantini dan Prabatmodjo (2013) petani memandang positif kebijakan disinsentif yang ditetapkan mampu membuat sebagian besar petani menjaga fungsi lindung dari sawah.

\section{KESIMPULAN DAN SARAN}

\section{Kesimpulan}

Berdasarkan hasil penelitian dapat ditarik kesimpulan sebagai berikut:

1. Karakteristik petani padi di Kecamatan Purbaratu yaitu umur sebagian besar petani berkisar berumur 53-64 tahun, luas lahan petani sebagian besar dalam kategori sempit ( $<0,5$ ha) sebanyak $70,87 \%$, sebagian besar pendidikan responden 88,35\% telah menyelesaikan pendidikan tingkat SD, mayoritas responden mempunyai pengalaman usahatani sebesar 38,35 \% yaitu petani memiliki pengalaman antara 11 sampai 20 tahun, tanggungan jumlah keluarga terbesar berada pada rentang 2-3 orang yaitu $54,86 \%$, pendapatan usahatani padi yaitu kurang dari Rp. 2.502.000,sebesar $79,61 \%$, dan status kepemilikan lahan sebesar 87,37\% didominasi status petani sakap.

2. Respon petani terhadap kebijakan insentif dan disinsentif dalam pengendalian lahan pertanian rata-rata petani sangat setuju dengan adanya jenis insentif karena sangat membantu dalam berusahatani. Petani setuju dengan adanya bentuk disinsentif supaya memberikan efek jera kepada petani untuk pengendalian alih fungsi lahan.

\section{Saran}

Berikut saran yang dapat diberikan oleh peneliti yaitu:

1. Frekuensi kedatangan penyuluh lebih intens dan teratur kepada petani maupun kelompok tani merupakan hal yang harus diteruskan, namun perlu juga dimasukkan materi mengenai LP2B kepada kelompok agar petani 
lebih memahami akan pentingnya kebijakan ini dan dampaknya bagi lahan pertanian.

2. Pemerintah sebaiknya lebih difokuskan pada pemberian bantuan insentif yang diprioritaskan petani seperti pupuk dan benih yang lahan sawahnya akan dijadikan LP2B serta sosialisasi mengenai kebijakan LP2B setidaknya dilibatkan seluruh petani secara aktif.

3. Kebijakan LP2B dibuat sedetail mungkin yang mampu mengakomodir kebutuhan petani dan kemampuan pemerintah serta ketegasan pemerintah dalam melaksanakan peraturan yang telah ada.

\section{UCAPAN TERIMAKASIH}

Penulis menyampaikan terima kasih kepada berbagai pihak atas bantuan, bimbingan dan saran. Ucapan terima kasih haturkan kepada kedua orang tua penulis yang memberikan support dan doa agar diberikan kelancaran dalam penyusunan tesis, Ibu Dr. Lies Sulistyowati, Ir., MS dan Prof. Dr. Maman Haeruman K., Ir., M.Sc selaku Dosen Pembimbing yang telah memberikan masukan dan pengarahan guna penyempurnaan penulisan tesis dengan penuh kesabaran.
Ibu Dr. Ir. Lucyana Trimo, MSIE, Bapak Dr. Ir. Trisna Insan Noor, DEA, dan Bapak Dr. Ir. Iwan Setiawan, SP., M.Si selaku dosen penelaah yang meluangkan waktunya dalam memberikan kritik dan masukan kepada penulis. Segenap Bapak/Ibu Dosen Program Magister Ilmu Ekonomi Pertanian Fakultas Pertanian Universitas Padjadjaran yang memberikan ilmu pengetahuan kepada penulis.

Berbagai pihak yang tidak dapat penulis sebutkan satu persatu. Khususnya rekan-rekan yang memberikan bantuan dan motivasi. Semoga Allah SWT memberikan pahala sebesar-besarnya kepada Bapak, Ibu dan Saudara atas kebaikan yang diberikan.

\section{DAFTAR PUSTAKA}

Badan Pusat Statistik. 2017. Luas Lahan Sawah Kota Tasikmalaya Tahun 2012 - 2016.

Dinas Pertanian Kota Tasikmalaya. 2017. Perkembangan Luas Lahan Sawah Kota Tasikmalaya.

Gustiyana, H. 2004. Analisis Pendapatan Usahatani untuk Produk Pertanian. Salemba empat: Jakarta.

Hairiah, Kurniatun., Widianto, Sri Rahayu Utami, Didik Suprayogo. 2000. Pengelolaan Tanah Masam Secara Biologi Refleksi Pengalaman dari Lampung Utara. Bogor. Indonesia.

Harsono, Boedi. 2007. Hukum Agraria Indonesia, Sejarah Pembentukan Undang-Undang Pokok Agraria, Isi dan Pelaksanaannya, Djambatan. Jakarta. 
Hernanto, Fadholi. 1996. Ilmu Usahatani. Jakarta: Penerbit Swadaya.

Ihrom, T.O. 1999. Bunga Rampai Sosiologi Keluarga. Jakarta : Yayasan Obor Indonesia.

Isa, I. 2004. Strategi pengendalian alih fungsi lahan pertanian, In Dalam: Dariah A, Nurida NL, Irawan, Husen E, Agus F, penyunting. Prosiding Seminar Multifungsi dan Revitalisasi Pertanian. Bogor (pp. 27-28).

Nurhasikin. 2013. Penduduk Usia Produktif dan Ketenagakerjaan. Artikel Badan Kependudukan dan Keluarga Berencana Nasional Kepulauan Riau.

Martianto, D., dan Ariani. 2004. Analisis Perubahan Konsumsi dan Pola Konsumsi Pangan Masyarakat dalam Dekade Terakhir. Widyakarya Nasional Pangan dan Gizi VIII "Ketahanan Pangan dan Gizi di Era Otonomi Daerah dan Globalisasi”. Jakarta.
Nadapdap, Hendrik. 2014. Kajian Adopsi Teknologi Produksi Komoditas Mangga. Universitas Padjajaran Bandung.

Rantini, R.R dan H. Prabatmodjo. 2013. Tanggapan Petani Terhadap Kebijakan Perlindungan Lahan Pertanian berkelanjutan di Kabupaten Bandung. Jurnal Perencanaan Wilayah dan Kota. Vol. 3 (2).

Wibowo, S.C. 1996. Analisis Pola Konversi Sawah Serta Dampaknya Terhadap Produksi Beras : Studi Kasus di Jawa Timur. Bogor : Jurusan Tanah Fakultas Pertanian Institut Pertanian Bogor.

Wijayanti, Ari. 2016. Kebijakan Perlindungan Lahan Sawah Dalam Mengatasi Alih Fungsi Lahan Sawah (Studi Kasus Di Kota Sukabumi, Propinsi Jawa Barat). Sekolah Pascasarjana Institut Pertanian Bogor. 